\title{
Tradition of "Falia" Local Wisdom as Cultural Capital in the Formation of Magnanimity of Muna Society
}

\author{
La Taena ${ }^{1}$, Ader Laepe ${ }^{2}$, La Ode Ali Basri ${ }^{3}$, La Miliha ${ }^{4}$, Asrun $\mathrm{Lio}^{4} \&$ I Ketut Suardika ${ }^{2}$ \\ ${ }^{1}$ Department of Social Science Education, Faculty of Teacher Training and Educational, Halu Oleo University, \\ Kendari, Indonesia \\ ${ }^{2}$ Department of Education and Social Science, Teacher Training and Educational Faculty, Halu Oleo University, \\ Kendari, Indonesia \\ ${ }^{3}$ Department of Antropology, Faculty of Cultural Science, Halu Oleo University, Kendari, Indonesia \\ ${ }^{4}$ Department of English Education Teacher Training and Educational Faculty, Halu Oleo University, Kendari, \\ Indonesia \\ Correspondence: La Taena, Department of Social Science Education, Faculty of Teacher Training and \\ Educational, Halu Oleo University, Kendari 93232 Sulawesi Tenggara, Indonesia. Tel: 62-813-4181-0002. \\ E-mail: lataena60@yahoo.co.id
}

Received: April 17, 2017

Accepted: June 8, 2017 Online Published: September 29, 2017

doi:10.5539/jsd.v10n5p217

URL: https://doi.org/10.5539/jsd.v10n5p217

\begin{abstract}
The tradition of 'falia' is the cultural local wisdom of the Muna community, as a specific culture is explored from their life experiences from generation to generation in the past. 'Falia' is a prohibition that cannot be violated either individuals or groups. However, it has been eroded by the era of globalization lately and its generation is slowly forgetting it, whereas the meaning of 'falia' has a universal humanism value, pedagogic which is used as a guide to create harmony and social order, has noble character.

The purpose of this study is to describe and analyze (1) forest preservation, (2) sex education, (3) respect for work performance of others, (4) work ethic, (5) ethics. The method used in this research is designed descriptively qualitative; located in Muna District; data collection is done by observation, interview and documentation. Data analysis technique is used by data reduction, data presentation, conclusion and verification. The results of this study found in the field are (1) advocating to conserve forests, (2) to avoid free sex, (3) to appreciate the services and works of others, (4) the Muna community is very tenacious, diligent, steadfast, and high work ethic, (5) they have good manners and ethics.
\end{abstract}

Keywords: falia, cultural capital, magnanimity, Muna community

\section{Introduction}

Each country has indigenous communities themselves which has a specific culture excavated from their life experiences in the past. One specific culture is a community-owned cultural of taboos or abstinence bans that should not be violated.There are some people who believe that if happen a violation of something that is taboo; it is believed that it will bring a penalty or sanction of nature imposed on offenders and the surrounding community. Thus, people who believe in the existence of taboo give a social sanction to anyone who violated the taboo. The goal is for people can be careful so as to avoid the violation of taboos and avoid sanctions of supernatural nature. In India for example, there is the doctrine that man, the seed and the soil is seen to relate to each other integrally. So there is a ban on the use of land which is not in accordance with their distribution, not in accordance with peculiarities of ecology and local culture (20). In African society, also found the existence of customary rules that prevent people from cutting down trees near waterways $(4) ;(16) ;(3)$ and (10).

Similarly, local wisdom in Indonesia has meaning such as local wisdom of ecology in NTT, the indigenous community of Sasak has a behavior management of natural resources that are taken over from generation to generation (15). Then, in Padang (West Sumatra) forest preservation efforts in the form of local wisdom, the same thing in Maluku and Papua local wisdom set integrated system of environment ecosystem (17). Dayaks in Borneo can overcome the problems of forest land that is not thriving (9). In Buton, existing evidence regarding local wisdom "seen from pemali in the didactic aspects of oral tradition of Ciacia community" (9). Similarly, 
Muna communities in the Southeast Sulawesi has a specific culture that is always inherent in the lives of Muna people, who then manifest in behavior and lifestyle of their daily life. One specific form of culture owned by the Muna people is Falia culture (Indonesian: pemali). Falia, in anthropology known as taboo is an abstinence that should not be violated by the Muna people either individually or in groups.

Muna Society has been maintaining and defending the values of Falia since long time ago (the 13th century, Muna kingdom era) in various areas of public life, but the strength of the modernization era in the current globalization era has resulted in the decrease of concern of Falia in Muna tradition. Today, the observer of Falia tradition is nearly extinct. Therefore, the tradition of Falia in Muna culture needs to be saved and preserved the noble values. This article will reveal the results of a study entitled Pedagogical Dimension in Cultural Meaning of Falia in Muna Society (11).

\subsection{Falia (Pemali) as Local Wisdom Which Has Oedagogical Values}

For Muna people, Falia is a social forbids or abstinence banned in public life that should not be violated either in the form of action or utterance. Falia exists in all aspects of community activities, related to human beings, human relationship with nature, as well as activities related to human's relationship with God. In a socio-cultural perspective, Falia is a moral norm because there is a set of universal humanity values used as guidelines by the community to create social order and harmony. (19), Falia is a tradition that became one of perspective of Muna people.

According to (19), tradition is a collection of custom, beliefs and practices that lead to a culture for sustainability. Falia is a collection of habits, beliefs practiced by Muna people about something that is prohibited or undesirable to be done or spoken by a person or group of people because it is considered taboo. However, there are elements of educational character that can shape the personality of community members to become better persons. Thus, Falia acts as a controller for a person (self-control) and for society collectively (social control) in order not to act bad temper, not to do anything againsts the law both customary and religious law, not to violate the norms of ethics and morality, and not to destroy nature (1).

At the cognitive level, Falia has pedagogical values which can shape the personality and human moral. Pedagogical values of Falia can be taught to students at school. As far as moral values are concerned, the role of education in society changes, it is not only to make children smart, but also to make them creative, critical, and have a resistance of global value that is less appropriate to local values. In a global civilization, society has resulted in a secular atmosphere (23), the task of school is to facilitate children with the local wisdom values in order to establish a strong character.

In this paper, the pedagogical values as learning material that derived from Falia is very potential to be extracted, and become a source of reference for educators to build a character that meet the personality of the nation. Moral and ethical messages are basic character of Falia to bulid a good personal behavior to be polite in speaking, behave ethically, noble character, and well character. Thus, Falia serves not only as a controller for the behavior of any person in order to avoid bad character and behave, but also as a form for the nation's character education.

Falia is believed to serve as a guide of life (way of life) for Muna people. Cultural values of Falia can be traced, turned on, and internalized as reference for educators to shape the character of the nation. According to (13), by internalizing the values of local wisdom in the learning process in schools expected to build a better community life.

\section{Research Methods}

The study was conducted in sis months in Muna Southeast Sulawesi in two sub-districts, Watupute and Katobu. Currently, in the two sub-districts, the society use the expression of Falia in the daily life. The informants were those who are well a ware and understand the culture of Muna, particularly Falia. The informants wre determined through a purposive and snowballing technique, in whch to get the next informant were based one thinformation of previous informant. The selected informants in this study were three customary figures, one community figure, one religious figure and one cultural observer. The data were collected through a variety of techniques and some instruments to facilitate filtering the data as follows:

(1) Observation, Observation technique was made on the socio-cultural conditions of Muna people who express Falia. The observations were conducted in the context of expression in Falia including: (1) to whom taboo expressions (expressed) addressed: children, teenagers, boy and girl; (2) the circumstances that taboo phrase expressed: formal (in the cultural procession of events) or informal (relaxed atmosphere), and (3) in how the taboo expressed: face to face (direct face to face) or indirectly through media. 
(2) Interview , The informants were interviewd though a gudied of intervie list. The implementation of interview techniques (interview) used a guideline instruments of interviews (interview guidance) which was a number of questions prepared to ask the informant. A number of questions were asked to the informants related to Falia practices. The researcehers applied in-depth interviews.

(3) Record Techniques (recording) and Note (noting), Recording technique was applied by recording the amount of data needed for more complete and comprehensive acquisition. The recorded data were taboo expressions in Falia expressed during the ongoing cultural procession ceremony. There were several ceremonies in the cultural procession of Muna society in which were disclosure taboo sentences as part of Falia. The recording techniques used instrument such as handy cam and tape recorder.

Noting technique was done by recording the amount of relevant data in this study. During the on-site research, the researchers found relevant data spontaneously in interaction with the local community. The data noted spontaneously to avoid the loss of data due to the limited memory of researchers. The noting used instruments such as card data that was always being carried by researchers in the field site.

\subsection{Data Analysis}

The data were analyzed by using a cultural perspectives approach. This approach used the perception and views of local communities (indigenuos people) in this regard as the cornerstone of Muna society in analyzing and interpreting the data.

Data analysis used descriptive analytic method, in this case the data were analyzed and interpreted based on the state of nature. In analyzing and interpreting the data, the reserachers did not involve elements of subjectivity, so the data were analyzed and interpreted entirely free from personal tendencies.

Phase of the data analysis were as follows:

(1) Reduction of data that summarizes, notes, coding, writing oral data into written data. Data of taboo expressions in Falia were trascribed in text. Then, translating the data from Muna language into Indonesian. The data classified into corresponding expression of taboo which were appropriate with the characteristic of data source in-depth interviews and observations.

(2) The data selected data were displayed in order to understand easily. The data in this study were shown in the form of quotations from interviews to maintain the authenticity of the data.

(3) Finaly, conclusion was the accumulation of preliminary conclusions with evidence of valid data from the meaning of taboo expressions in education. The conclusions of this research were directed to answer the research problems which describes pedagogical dimension in culture of Falia in Muna society (7).

\section{Results and Discussion}

\subsection{Pedagogical Dimension of Falia: Preserving the Environment and Forest}

Falia in Muna society also contain ecological wisdom which is recommended to preserve nature. Muna communities have customs and cultures that contain environmental protection embodied in the life together. Muna people view nature not only as objects to be conquered or exploited solely for worldly satisfaction, but the universe is a part of life and is a source livelihood that must be kept and maintained sustainability. This view is in line with the findings of (23) that in cosmology, Muna people who created this world is called Ompu. Because of that Falia arbitrary act against nature will face the wrath of the Almighty.

Therefore, the ancestral of Muna create tool of human behavior controller in the move included in the environmental preservation activities called Falia for Muna society. It contains recommendation to preserve the environment, such as the prohibition of cutting down trees, especially if the tree is vicinity of the clean water source. One of the elders of Muna people stated that "O falia dekati-katinda laano sau, bhita nofohimugho tungguno maka domosaki", Translation: Faliha bans cutting wood, because if they are chastened by the watchman guards, then we can be sick (interview with La Sola, in his home in the Village of La Bolu, Muna on August 5, 2013).

Ideology of Falia above is the preservation of ecology, because until now Muna people still believe that the tree is one of the residences of spirits. These spirits can do an evil and harm things to human. So, people of Muna are very careful in cutting down trees. They are even very convinced of the existence of spirits that inhabit the trees, then when passing or being around trees, especially large trees, there are some people who feel noere wulu (makes our hair on body trembling especially on the hands) or nosigari wuluno langhumana (makes our hair on body trembling to the head). This kind of feeling is the control device, so that, community members are not indiscriminate in doing logging or excessive encroachment. The result, (9), research thet the conclution thet the 
rules of tradisional on a comunity Muna advokating to preserve ot the forest.

If people want to cut down trees or open new land, local people always begins with a ritual called fesolo, which is a ritual to ask permission to supernatural beings that exist around in the opening land or the trees. This ritual is led by a shaman who is considered to have magical powers that able to communicate with the spirits. This is supported by the findings of (23), that the natural environment is not only humans who occupied inhabit, but there are other creatures (supernatural beings) who inhabit, so that humans should be careful in the act and behave.

Other Falia also contains the value of ecological preservation called ofalia dobhose bhe deghoro sabhara hula we undalo nofogintaane embu, translation: Falia sailing while throwing all sorts of objects in the sea as it will be pulled by a giant octopus (interview with Justona at home in Bangkali village, Muna dated on August 12, 2013). In sailing, it is recommended not to throw garbage in the sea, and when it was done, it is considered as Falia; impact of the act is the ruler of the sea rage known as embu 'giant octopus' which will pull the ship to the bottom of sea. This Falia teaches us not to pollute the sea. Disposing waste at sea results marine pollution that lead to the damage of marine ecosystem.

The meaning of ecological preservation in Falia reinforces the thesis that in all societies everywhere, especially in Indonesia always have the wisdom in managing the environment around them. Fo example in NTT, indigenous people of Sasak has knowledge system and processing of natural resources and ecology and inherited from generation to generation (15). Furthermore, all forms of knowledge, beliefs and customs, ethics that guide human behavior in life requires an ecological community. Similarly, in the area of Padang (West Sumatra) every effort to maintain the forest is a form of local wisdom, it can be lived, practiced, taught, took over from generation to generation as well as forming a pattern of human behavior, nature, the environment and the occult (19).

On the other communities in Maluku Islands, mostly in Papua have local wisdom "inside found the settings system of allocation or land-use and integrated management of terrestrial and marine ecosystems are local specialties", complete with traditional institutions which guarantee the local system is working effectively (17). Examples of institutions of custom found mostly in Maluku that govern the sustainability of an area and a specific biological types. Another example is indigenous communities of Dayak people in Borneo local wisdom can overcome the problems of infertile land (7). In India, there is a doctrine that human, seed and soil are seen to relate to each other integrally. So, there is a ban on the use of land which is not in accordance with their distribution, not meet the peculiarities of ecology and local culture. In African society, also found the existence of customary rules that prevent people from cutting down trees near waterways, (4), (16), (3) and (10). In addition, (18) states that memorial agricultural systems adopted by prime farmers (manor estate) in the Middle Ages also has ecological wisdom because the landlords always take advantage in the way and culture of farming community around their manor.

Falia in environmental management of the Muna culture also corroborate the findings, (19), (21), (22), (20) that local wisdom in every region in Indonesia has the diversity and commonality, where the teachings core always advocate the need of environmental conservation, as a source of human life that needs to be maintained (9), (10), dan (12).

\subsection{Sex Education to Avoid Free Sex Acts}

Free sex act is sexual relations outside the marriage bonds. This free sex act occurs as a result of western culture impact. The extramarital sex behavior is contrary to religious and socio-cultural values in Indonesia society. However, today, many teenagers who engage in the practice of free sex. BKKBN survey in 2010 (2) showed that 20.6 percent of adolescent pregnancy and extramarital childbirth (www.gkpb.net/item/survey) accessed on November 17th 2013 (25), (26).

Meanwhile, in many media mention that the recent immoral is in anxious level. The case of sexual obscenity becomes increasingly frequent to be sexual abuse that has continued to break out in the middle of society. Teenagers often become the victim of the actions of the perpetrators of this misconduct. Indonesian Police Watch (IPW) said, more than fifty cases of abuse occurred in this country in 2013. Although they did not mention the exact number, IPW said, in the first month of this year, there were at least 23 cases of rape occurred in Indonesia. Almost half of that number, parties who are victims from adolescents (Republika.co.id), downloaded November 17th 2013. This free sex act can be avoided by socializing sex education from an early age through Falia culture in Muna society. In relation to Falia, Muna society are banned to have sex at any place. It can be observed in the passage of "ofalia dopokawite - wite rampano nosungkuane wewi" translation: Falia of soil game for causing fierce crop pests. If we examine more deeply the Falia phrase " soil-game causing the ferocity of plant pests" are 
two unrelated propositions". There is no relationship between the soil-game and such ferocity plant pests. One of the community leaders of Muna (interviewed La Ode Sirad Imbo ,di Watonea in his home in Watonia sub-district, Muna dated on August 14th 2013) stated that, Falia has the connotative meaning that Muna people should not be having free sex, because it can lead to the destruction of the relevant actors and local communities.

Another informant, (interviewed La Sola at his home in the Sub-District of La Bolu, Muna dated on August 4th, 2013) stated that, in the etymology of the word "dopokawite - wite" consists of two syllables that dopokawi means mating has the synonymous with sex, and wite which means land. In terminology dopokawite - wite is a sexual activity that takes place on the ground. In view of the Muna society that behavior is a form of moral aberration as opposed to the customs of the local people, so that not only disowned by humans, but also by God and other creatures. One of the forms of the wrath of God is sending or moving the animals/animals for his creation to crush communities plant that violate falia dopokawite - wite. Thus, society will experience crop failures that threaten for famine. Therefore, the ancestors of Muna fortify his generation not to have sex freely through the norm called falia dopokawite wite(11).

\subsection{Apreciating the Efforts, Inventions and Thoughs of Others}

Falia in Muna society also contains values that provide guidance, so that people learn how to appreciate the services and the work of others. Human beings must respect the results of operations, creation, and the results of public opinion. In the point of view of Muna people, appreciating the work and services of others is one way to foster aptitude and harmony among human life in order to realize a society that respect each other and respect the dignity in accordance with the degree of a person as a human being. The conception of this kind can be found in the concept of Falia "ofalia detongka kahitela atawa dotobhe ane minaho natumandakie parikano rampano mina nakoinawaane kahitela be pae" translation: Falia "pemali" reap the harvest of corn or rice if it is not preceded by parika ( a farm shaman) as it causes no corn or rice has spirits). Parika is a person who has been instrumental in sowing the seeds and start planting (corn/rice) and those who already communicate with supernatural beings in the area around the farm. So on harvest time, he always takes precedence in initiating harvest activity. The habit of preceding Parika is inherent in the culture of farming in Muna communities. Rice or corn which is ready for harvest is often late harvested just because the crop procession has not been conducted yet (preceded) by Parika.

In addition, other Falia teaches to respect the work and services of others can be observed on the prohibition to leave the house, if food or drink has been served. One of the customary leaders of Muna society stated that "Ofalia doere dokala anekaalahino nefumaa atawa okaforoghu nentaa-ntamoa, rampano dewiseki balaa" translation: Falia "pemali" leaving the house when the food or drink has been served will cause bad thing". The serving of food and beverage is the shape of kindness and breeding to us, so we should appreciate the favor by tasting the dish. When leaving home without tasting dish that has been served, that means we do not appreciate the kindness of people who serve the food, (interview with Sola at his home in the Sub-District of Bolu, Muna on August 10th, 2013).

The second cultural value of Falia is to appreciate and cherish the goodness of others. In social life, appreciate and respect the work of others can create social harmony, so people life will run calm and peace because everyone will realize the importance of mutual respect. In addition, fostering respect for the work and services of others is commendable attitude as it is a personal reflection of its creator as a human who wants to be appreciated (11).

\subsection{Work Ethic and Hardwork Spirit}

Falia in Muna society also contains the spirit of hard work and responsibility. This is implied in "falia detangku-tangku ghase, nomate ana kamokula" translation: Falia of leaning chin on our hand can cause the death of parents. Leaning chin on hand is the attitude or actions that are so hated by the people of Muna because his it is the characteristic of lazy people, indifferent life, not creative and tend to be passive. The lives of people who have a habit like this is not going forward, static because he is always surrounded by laziness, sadness and apathetic. Therefore, people hate this behavior.

Other Falia contains life success motivation that is "ofalia dempolodo-lodo samintaeno, mina dakoradhaki ane" translation: Falia of sleeping in the morning can cause less of blessing. Even in one of the public works concept of Muna stated that people who get up late in the morning, his food has been eaten by chickens. (interviewed La Daga in his home in the village of Watuputih, Muna on August 15th, 2013). The public philosophy view of Muna is that the people should have the mentality and a high work ethos, tough, tenacious and unyielding. In view of Muna, hard work is part of the teachings of the ancestors, so the hard work becomes part of their life. There is an advice from Muna who taught that Muna people are tough and full responsibility worker. The advice is "fekamara-marasai koana omarasai, koemo marasai omarasaigho" translation: do not feel so poor to be poor, 
and feel poor in order not to be poor.

The advice contains the spirit of hard work and responsibility. The conception of hard work is also as a reflection that Muna poeple are creative, tenacious and diligent and highly motivated to succeed or excel, toward a better life change. McClelland (6) stated that the change is determined by the presence of individuals who have the motivation to succeed, because such individuals will work harder, learn faster and they will feel inner satisfaction when successfully complete the job perfectly (9).

\subsection{Ethics}

In Falia, there is ethical values as guidelines for community of Muna in to act and to behave in daily social life. Thus, with this ethics, Muna people can put themselves well and truly in the form of society life. Falia contains elements of ethics as guidance in attitude and action.

Falia contains elements of ethic can be observed in the Falio of "ofalia dengkora ne kandulua nokokawisuane kamio" translation: Falia of sitting on a pillow can cause growing a boil on the ass. In the perspective of people pillow is a place for head, in which the head is a symbol of honor and dignity of someone. So, people will be upset if someone deliberately call or nudge their head. Therefore, this pemali gives guidance to the society to pu something according to its function. According to, (interviewed La Ode Arqam Ali at his home in Sub-District of Abeli, Kendari City on August 18th, 2013) falia "pemali" actually teaches us to respect fellow human beings with no hurt feelings such as issuing rant or rude words. That is because ulcers in pemali is a symbol of representation of "dirty and ill" experienced by a person. Therefore, "ofalia dengkora ne kandulua nokokawisuane kamio" (pemali sitting on a pillow as it will grow pain in the ass), is a medium to convey the moral message.

Other Falia which has ethical teachings is "ofalia dofumaa ne nuhua rampano noghitoane hula" translation: Falia of having a meal in a pot can blacken the face," and ofalia defenami kagau ne kasiki newantaane nunsu. Eating in the pot is not polite, so that is considered Falia. The impact is the face to become black, as the black the bottom of the pot. Eating in a pot is a sign of something indecent or impolite because the pot is cooking tool that is not for eating media. In addition, eating in a pot is seen as less ethical because the food is left to be eaten by others.

Likewise, the "falia defenami kagau ne kasiki newantaane nunsu" translation: Falia of tasting dishes in a large spoon can cause the lips growing longer "Kasiki" is large spoon used for stirring food in a pot. Tasting dishes in 'big spoon' is considered reckless, undisciplined, and disrespectful. Therefore, the tasting food in a large spoon (Kasiki) is considered as Falia that can lead to the prolonged nunsu 'upper lip'. Moral teaching delivered behind this Falia is a discipline and courtesy. For Muna people, tasting dishes have to be done by dropping it on the palm of the hand, not by tasting it on large spoon because the large spoon will be used for stirring food in a pot.

Meanwhile, La Ode Sirad Imbo, (interviewed at his home in the of Watonea sub-disctrict, Muna on August 14th, 2013), stated that Falia in Muna society also contains ethic about property ownership. It can be found in "falia depake/deala hakunaasi rampano nobinasaane mbhada dhunia ahera" translation: Falia of taking away the rights of the ill-fated cause the destruction of body of the world hereafter. The term of haku naasi 'rights of the ill-fated' in the Falia phrase above is a meaningful symbol of 'rights of others' either moving or not moving property. Taking or using hakunaasi 'rights of the ill-fated' is very taboo in society of Muna. If this Falia is violated, it can result in the destruction of the world and the hereafter, meaning that the perpetrators will not survive in this world and hereafter. Thus, this Falia gives us the clue not to justify the means in achieving the desired objectives, including the purpose of collecting treasures.

From the above explanation, it is obvious that Falia is phrases and symbolic behavior that contains a lot of meaning, which is always interpreted by the people of Muna as a guide for them to interact and interelate in social life. This is in line with the view of Cassirer (14) that the human act often uses symbols, because with the symbols human would create a solution to overcome life's difficulties and their ignorance. So, (5) called human beings as homo interpreticum because of its ability in interpreting the sign or symbol. According to (5), The world is full of signs, people interpret it as a guideline in this context of life. In this context, then Falia is one of signs in which there is hidden meaning of the universe that is immeasurably extent (11).

\section{Conclusion}

This study found some conclusions.

1) Pemali in Muna society contains suggestion of ecological wisdom, nature conservation, custom of environmental preservation, part of life and source of life that must be kept and maintained its preservation. It is a prohibition of muna people to cut trees randomly, especially if the tree is located around clean water. The 
speech in Muna language ofalia dekati-katinda laano sau bheta nofohimoghao tungguno sau maka domanansaki, it means that it is forbidden to hurt or cut wood, because you will get reprimand by the guardian of that tree, then we can get sick.

2) Free sex education based on our findings in the field is very contrary to the cultural values of Muna, due to free sex, because it can lead to destruction of their moral and behavior.

3) Appreciate the work performance of other people

Muna society gives a guidance so that human learn to appreciate service and result of others, muna society appreciate professional person which is one effort to develop aptitude and harmony of life among human being to realize mutual respect in accordance with one's dignity and professionalism.

4) High work ethic

Muna community is hardworking, responsible, tough and disciplined people. They have motivation to live successfully. They are also creative, diligent and patient in facing all life challenges.

5) Ethics

Pemali owned by Muna community has ethics that is the source of acting and behaving in their social life every day.

\section{References}

Badan Kependudukan Keluarga Berencana Nasional. (2010). (in Indonesian).

Doroigbo, C. I., Ibeawuchi, II., Aja, O. O., \& Ejiogu-Okereke, E. N. (2011). Indogenous Technologies for Adaptation and Mitigation of Climate Change in Sub-Sahara Africa. International Journal of Agriculture and Rural Development, 14(2), 630-637.

Durruna, C. S., Chiaka, II., Ebenebe, O. E., Udedibie, A. B. I., Uchgbu, M. C., \& Durruna, O. N. (2011). Value of Bitter Leaf (Vemonia amigdalina) Meal as Freed Ingredient in the Dief of Finisher. International Journal of Agriculture and Rural Development, 14(2), 722-726.

Eco, U. (2004). Tamasya Dalam Hiperealitas. Jalasutra, Yogyakarta (in Indonesian).

Fakih, M. (2000). Masyarakat Sipil untuk Transformasi Sosial: Pengelolaan Ideologi di Dunia LSM Indonesia. Pustaka Pelajar, Yogyakarta (in Indonesian).

Huberman, A. Mi., \& Mathew, M. B. (1992). Analisis Data Kualitatif. Penerbit: UI-PRES, Jakarta (in Indonesia).

Koire, O. C., Eze, C. C., Lemchi, J. L., Orebiyi, J. S., Obasi, P. C., Ohajianya, D. O., \& Eza, U. E. (2011). An Overview of Benefits of Organic Agriculture as a Climate Change Adaptation and Mitigation Strategy for Nigeria. International Journal of Agriculture and Rural Development, 14(2), 638-645.

Laepe, A. (2006). Analisis Seometik Atas Lirik Kantola Sastra Lisan Daerah Muna.

Megawangi, R. (2009). Menyemai Benih Karakter. ViscomPratama, Jakarta(in Indonesian).

Mulyana, D. (2008). Ilmu Komunikasi: Suatu Pengantar. PT. Remaja Rosdakarya, Bandung (in Indonesian).

Nababan. (2003). Pengelolaan Sumber Daya Alam Berbasis Masyarakat Adat. Tantangan dan Peluang. Retrieved from http://dte.gn.org./makalattg psda berb-ma di pplh.htm

Okoronko Wo, M. O., \& Mbah, O. (2011). Resource Use Efficiency by Rural Poor Cassava Farmers in Imo Statel Implication for Poverty Alleviation. International Journal of Agriculture and Rural Development, 14(2), 610-613.

Pietersz, J. H. (2009). Dari Aturan Adat ke Etika (Kearifan Lokal) dan Peraturan Lingkungan Modern Dalam Hubungannya dengan Kelestarian Lanskap (Kajian Berdasarkan Pengalaman Kasus di Pulau Saparua, Propinsi Maluku). Unpati Ambon Press. (in Indonesian).

Pranowo, B. (1998). Islam Faaktual Antara tradisi dan Relasi Kuasa. Adicita Karya Nusa, Yogyakarta (in Indonesian).

Prasad, R. (2005). Organic Farming Vis-a-vis Modern Agriculture. Curent Science, 89(2).

Pretty. (1990). Memorial Agriculture System. Local Institution Development. IIED. London.

Rasyidi, M. (2008). Studi Nilai Budaya Pada Lembaga Adat Suku Sasak Sebagai Kekuatan Dalam Membangun Nilai-Nilai Budaya Bangsa. Agroteksos, 18(1-3). (in Indonesian). 
Sartini. (2004). Menggali Kearifan Lokal Nusantara, Sebuah Kajian Filsafat. Jurnal Filsafat, Jilid 37; Universitas Gajah Mada. Yogyakarta (in Indonesian).

Semiawan, C. (2008). Belajardan Pembelajaran Pra sekolah dan Sekolah Dasar. PT Indeks, Jakarta (in Indonesian).

Suyuti, N., \& Aris. (2007). Bentuk Kearifan Lokal dalam Menjaga Kelestarian Lingkungan Hidup pada Suku Bangsa Wuna di Kabupaten Muna, Dalam: Mengungkap Kearifan Lingkungan Sulawesi Tenggara, Penyunting: Muslimat dan Wakit Hasim, Masagena Press, Makassar (in Indonesian).

Taena, L., \& Balawa. (2009). "Pemali": Aspek Didaktik dan SemiotikTradisi Lisan Masyatakat Ciacia di Kabupaten Buton dimuat dalam Buku Prosiding Internasional Symposium on Cultural Studies "Exploring Cultural Stadies Implementing Emancipations" Denpasar, 27-28 Agustus 2009, Pustaka Larasan (in Indonesian).

Taena, L., Basri, L. O. A., \& Laepe, A. (2013). Aspek Pedagogik yang Terkandung dalam Kearifan Lokal "falia" pada Etnik Muna Sulawesi Tenggara. Oleh Kemristekdikti UHO (in Indonesian).

Taena, L., Basri, L. O. A., \& Laepe, A. (2014). Dimensi Pedagogik dalam Makna Budaya "falia" pemali pada Masyarakat Muna. Jurnal Mudra Seni Budaya, 29(1). (in Indonesian).

Taena, L., Sailan, Z., Nalevo, L., Basri, L. O. A., Laepe, A., Syamsul ... Wa Kuasa. (2016). The Cultural Traditional of " Falia " in Preserving Forest by Munanese Ethnic. Journal of Sustainable Development, 9(5). https://doi.org/10.5539/jsd.v9n5p200

www.gkpb.net/item/survei.praktik seks bebas, diakses tanggal 17 November 2013 (in Indonesian).

www.Republika.co.id, Meredam tindakan asusila, diunduh tanggal 17 November 2013 (in Indonesian).

\section{Copyrights}

Copyright for this article is retained by the author(s), with first publication rights granted to the journal.

This is an open-access article distributed under the terms and conditions of the Creative Commons Attribution license (http://creativecommons.org/licenses/by/4.0/). 